\title{
The correlation between left ventricular ejection fraction and clinical severity of manifestations in subjects with Coronary Artery Disease
}

\author{
Gloria-Bottini $F^{1 *}$, Saccucci $\mathrm{P}^{1}$, Banci $\mathrm{M}^{2}$, Neri $\mathrm{A}^{1}$, Magrini $\mathrm{A}^{\mathbf{1}}$ and Bottini $\mathrm{E}^{\mathbf{1}}$ \\ ${ }^{1}$ Department of Biomedicine and Prevention, School of Medicine, University of Rome Tor Vergata, Rome, Italy \\ ${ }^{2}$ Department of Cardiology, Valmontone Hospital, Italy
}

\begin{abstract}
We have studied the correlation between Left Ventricular Ejection Fraction (LVEF) and severity of clinical symptoms classified according to New York Health Association (cNYHA) in subjects admitted for Coronary Artery Disease (CAD). Two hundred subjects were considered. Informed Consent was obtained by the patients and the study was approved by the Ethical Committee. The following variables were examined: ACP1 genotype, p53 codon 72 genotype, age, sex, diabetes, obesity, hypertension, total cholesterol, history of previous infarction. Statistically significant differences in the correlation between LVEF and cNYHA were observed for ACP1 genotypes, sex and age. Carriers of * $\mathrm{C}$ allele of ACP1, females and subjects aging more than 65 years show a higher correlation between LVEF and cNYHA as compared respectively to other ACP1 genotypes, males and subjects aging 65 years or less. The correlation between LVEF and cNYHA increases with the number of variables for which an increase of such correlation has been observed.

The data suggest that subjects with CAD aging more than 65 years who carry *C allele of ACP1 if show a LVEF lower than $50 \%$ have a high probability to manifest severe clinical symptoms.
\end{abstract}

\section{Introduction}

A very useful index of ventricular function based on echocardiography is the Ejection Fraction (E.F.) which is the systolic volume divided by the end-diastolic volume. A normal E.F. is 0.55 or greater.

The clinical classification of patients with heart disease proposed by the New York Hearth Association (NYHA) is based on the severity of symptoms. Class 1, patients with no limitation of activities: they suffer no symptoms from ordinary activities. Class 2, patients with slight, mild limitation of activity: they are comfortable with rest or with mild exertion. Class 3, patients with marked limitation of activity: they are comfortable only at rest. Class 4 , patients who should be at complete rest, confined to bed or chair: any physical activity brings on discomfort and symptoms occur at rest.

The correlation between echocardiographic and clinical parameters has been scarcely considered in the literature. In the present note we have analyzed in subjects with coronary artery disease (CAD) the correlation between the two parameters in relation to variables that have a significant role in the susceptibility and in the clinical course of the disease.

\section{Material and methods}

We have studied 200 subjects admitted to the Hospital for CAD. Clinical data on these subjects have been reported in a previous paper [1]. $\mathrm{ACP}_{1}$ and p53 codon 72 genotypes were determined by DNA analysis as previously reported [1,2]. Informed Consent was obtained by the subjects and the study was approved by the Council of Department.
Statistical significance of difference between correlation coefficients was calculated according to Snedecor and Cochran [3]; other analyses were performed by commercial software (SPSS) [4].

\section{Results}

Table 1 shows the correlation between LVEF and cNYHA class in relation to nine variables including $\mathrm{ACP} 1$ and $\mathrm{p} 53$ codon 72 genotypes in patients admitted for CAD. Differences between correlation coefficients are statistically significant for $\mathrm{ACP}_{1}$, sex and age. The correlation is stronger in females than in males, in subjects aging more than 65 than in those aging 65 yrs or less and in carriers of ${ }^{*} \mathrm{C}$ allele as compared to other $\mathrm{ACP}_{1}$ genotypes. The table also shows the difference between squared $r_{s}$, a parameter that measures the proportion of variance of cNYHA class explained by LVEF i.e., the strength of correlation between the two variables.

We have considered the three variables for which the difference between correlation coefficient is statistically significant and depicted in Figure 1 the relationship between the number of factors for which an increase of $r_{s}$ between LVEF and cNYHA has been observed and the strength of negative correlation $\left(\mathrm{r}_{\mathrm{s}}^{2}\right)$ between the two parameters: the minimum value is observed when no factor is present and a maximum

Correspondence to: Fulvia Gloria-Bottini, MD, Department of Biomedicine and Prevention, University of Rome Tor Vergata, School of Medicine, Via Montpellier, 100133 Rome, Italy; Tel: ++39+6 30889514, E-mail: fulvia.gloria@uniroma2.it

Received: September 12, 2016; Accepted: October 10, 2016; Published: October 14,2016 


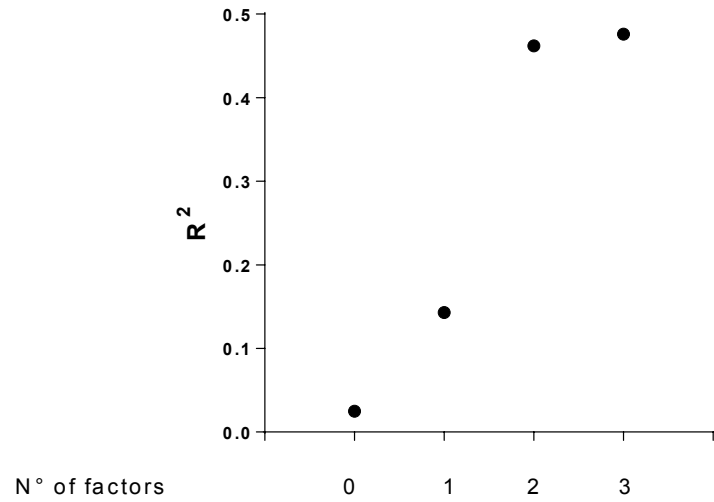

Figure 1. The relationsip between the number factors for which an increase of correlation between LVEF aand cNYHA has been observed and the strength $\left(\mathrm{R}^{2}\right)$ of correlation between the two variables. In this figure only $\mathrm{ACP}_{1}$, age and sex have been considered.

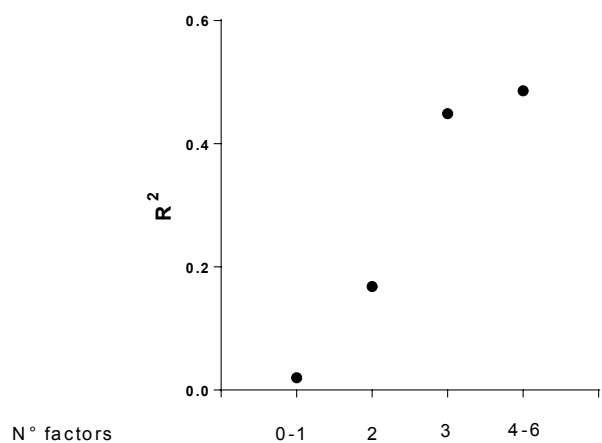

Figure 2. The relationsip between the number factors for which an increase of correlation between LVEF aand cNYHA has been observed and the strength $\left(\mathrm{R}^{2}\right)$ of correlation between the two variables. In this figure the following variables have been considerd: $\mathrm{ACP}_{1}$, sex, age, positive history of previous infraction, obeity and diabetes. when at least two factors responsible for the increase of correlation are present. The figure suggests that the predictive value of LVEF on the severity of clinical symptoms (i.e., cNYHA) is increasing with the number of factors present in the patient.

Figure 2 shows a similar analysis considering $\mathrm{ACP}_{1}$, sex, age, diabetes, obesity and positive history of previous infarction. The pattern of relationship between the number of variable and $r_{s}^{2}$ is similar to that observed in Figure 1.

In Table 2 we have considered a combined variable LVEF/cNYHA in order to analyze the concordance of severity of both LVEF and cNYHA with $\mathrm{ACP}_{1}$, age and sex. The concordance between the severity of the two parameters is much higher in subjects carrying the ${ }^{\star} \mathrm{C}$ allele of $\mathrm{ACP}_{1}$ that in other $\mathrm{ACP}_{1}$ genotypes. The concordance is much higher in subjects aging 65 years or more than in subjects aging less than 65 years. The concordance is higher in females than in males but such difference doesn't reach the level of statistical significance.

\section{Discussion}

Our analysis shows that the correlation between LVEF and cNYHA class in CAD is dependent on many variables. Considering cumulatively the effect of the variables examined the correlation doesn't exceed 0.7 suggesting that about $50 \%$ of cNYHA variance can be explained by LVEF.

The most important variables are $\mathrm{ACP}_{1}$ and age: subjects aging more than 65 years carrying the ${ }^{\star} \mathrm{C}$ allele of $\mathrm{ACP}_{1}$ and showing a LVEF lower than $50 \%$ have a high probability to manifest severe symptoms.

$\mathrm{ACP}_{1}$ controls the synthesis of cytosolic Low Molecular Weight Protein Tyrosine Phosphatase (cLMWPTP), a polymorphic enzyme showing quantitative variation of enzymatic activity among genotypes. There are three codominant alleles with enzymatic activity increasing

Table 1. Correlation between LVEF and cNYHA class.

\begin{tabular}{|c|c|c|c|}
\hline & $\mathbf{r}_{\mathrm{s}}$ & $\mathbf{r}_{\mathrm{s}}^{2}$ & Significance of difference \\
\hline 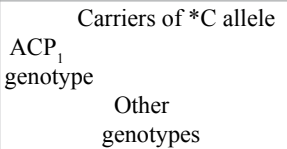 & $\begin{array}{l}-0.632 \\
-0.332\end{array}$ & $\begin{array}{l}0.399 \\
0.110\end{array}$ & $\mathrm{p}=0.035$ \\
\hline $\begin{array}{|cc|}\text { Sex } & \text { females } \\
& \text { males } \\
\end{array}$ & $\begin{array}{l}-0.554 \\
-0.334\end{array}$ & $\begin{array}{r}0.307 \\
0.112 \\
\end{array}$ & $\mathrm{p}=0.045$ \\
\hline $\begin{aligned} & \geq 65 \mathrm{yrs} \\
\text { Age } & <65 \mathrm{yrs}\end{aligned}$ & $\begin{array}{l}-0.622 \\
-0.368\end{array}$ & $\begin{array}{r}0.387 \\
0.135 \\
\end{array}$ & $\mathrm{p} \sim 0.050$ \\
\hline $\begin{array}{c}\text { yes } \\
\text { Positive history } \\
\text { of previous infarction } \\
\text { no }\end{array}$ & $\begin{array}{l}-0.605 \\
-0.423\end{array}$ & $\begin{array}{l}0.366 \\
0.179\end{array}$ & $\mathrm{p}=0.140$ \\
\hline $\begin{array}{ll} & \text { yes } \\
\text { Obesity } & \\
& \text { no }\end{array}$ & $\begin{array}{l}-0.537 \\
-0.348\end{array}$ & $\begin{array}{r}0.288 \\
0.221\end{array}$ & $\mathrm{p}=0.170$ \\
\hline $\begin{array}{ll}\text { Diabetes } & \text { yes } \\
& \text { no }\end{array}$ & $\begin{array}{l}-0.486 \\
-0.323\end{array}$ & $\begin{array}{r}0.236 \\
0.104\end{array}$ & $\mathrm{p}=0.180$ \\
\hline $\begin{array}{r}\text { high } \\
\text { Total cholesterol }{ }^{\circ} \\
\text { low }\end{array}$ & $\begin{array}{l}-0.508 \\
-0.430\end{array}$ & $\begin{array}{l}0.258 \\
0.185\end{array}$ & $\mathrm{p}=0.790$ \\
\hline $\begin{array}{l}\text { *Pro carriers } \\
\text { p53 codon } 72 \\
\text { genotype } \\
\\
\end{array}$ & -0.531 & 0.282 & $\mathrm{p}=0.800$ \\
\hline $\begin{array}{r}\text { yes } \\
\text { Hypertension }^{\circ \circ} \\
\text { no }\end{array}$ & $\begin{array}{l}-0.546 \\
-0.491\end{array}$ & $\begin{array}{r}0.289 \\
0.241\end{array}$ & $\mathrm{p}=0.900$ \\
\hline
\end{tabular}

${ }^{\circ}$ Total cholesterol: high $>200 \mathrm{mg} / \mathrm{dl}$

${ }^{\circ}$ Hypertension: arterial tension $\geq 130 / 85 \mathrm{mmHg}$ 
Table 2. The effect of $\mathrm{ACP}_{1}$, age and sex on the concordance between severity of LVEF and cNYHA parameters.

\begin{tabular}{|c|c|c|c|}
\hline $\mathbf{A C P}_{1}$ & $\begin{array}{c}\mathrm{ACP}_{1} \text { genotypes carrying the } \\
{ }^{*} \mathrm{C} \text { allele }\end{array}$ & Other $\mathrm{ACP}_{1}$ genotypes & Chi square test of independence \\
\hline $\begin{array}{c}\text { LVEF }<50 \\
\text { and } \\
\text { cNYHA class } \geq 3 \\
\text { total } n^{\circ}\end{array}$ & $\begin{array}{r}30.7 \% \\
39\end{array}$ & $\begin{array}{r}8.1 \% \\
161\end{array}$ & $\begin{array}{rcc}\chi^{2} & \text { df } & p \\
12.782 & 1 & 0.00035 \\
& \text { OR=5.00 } \\
95 \% & \text { C.I. } 1.91-13.41\end{array}$ \\
\hline AGE & $\geq 65$ yrs & $<65$ yrs & \\
\hline $\begin{array}{l}\text { LVEF }<50 \text { and } \\
\qquad \text { cNYHA class } \geq 3 \\
\text { total } \mathrm{n}^{\circ}\end{array}$ & $\begin{array}{r}24.8 \% \\
133\end{array}$ & $\begin{array}{r}1.5 \% \\
67\end{array}$ & $\begin{array}{ccc}\chi^{2} & \text { df } & p \\
15.558 & 1 & 0.00008 \\
\text { OR=21.78 } \\
95 \% & \text { C.I. } 3.07-100.68\end{array}$ \\
\hline SEX & females & males & \\
\hline $\begin{array}{c}\text { LVEF }<50 \\
\text { aNYHA class } \geq 3 \\
\text { total } n^{\circ}\end{array}$ & $\begin{array}{r}15.5 \% \\
91\end{array}$ & $\begin{array}{r}9.2 \% \\
109\end{array}$ & $\begin{array}{ccc}\chi^{2} & \text { df } & p \\
1,800 & 1 & 0.180 \\
& \text { OR=1.95 } \\
95 \% & \text { C.I. } 0.77-4.99\end{array}$ \\
\hline
\end{tabular}

in the order ${ }^{\star} \mathrm{A}<{ }^{\star} \mathrm{B}<{ }^{\star} \mathrm{C}$ and correspondingly six genotypes. The enzyme acts as phosphotyrosine phosphatase and as flavin-mononucleotide phosphatase [5]. The cLMWPTP dephosphorylates a negative phosphorylation site in ZAP 70 tyrosine kinase in T cell [6] with important effect on the activity of these cells. The enzyme is involved in the negative modulation of insulin signal transduction, in flavoenzyme activity and in dephosphorylation of Platelet Derived Growth Factor (PDGF) receptor $[5,7,8]$. Recent studies suggest that PDGF exert a protective role on contractile function of cardiomyocite and protects these cells from apoptosis [9].

The present study could have clinical relevance in CAD for the prognostic value of LVEF on the clinical severity of the disease. The main limitation is represented by the relatively low number of the subjects examined.

\section{References}

1. Banci M, Saccucci P, D'Annibale F, Dofcaci A, Trionfera G, et al. (2009) ACP1 genetic polymorphism and coronary artery disease: an association study. Cardiology 113: 236-242. [Crossref]

2. Ammendola M, Gloria-Bottini F, Sesti F, Piccione E, Bottini E (2008) Association of p53 codon 72 polymorphism with endometriosis. Fertil Steril 90: 406-408. [Crossref]

3. Snedecor GW, Cochran WG. Statistical Methods, Eight Edition, Iowa State University Press /Ames

4. Nie NH, Hull CH, Jenkins JG, Steinbrenner K, Bent DH. Statistical Package for the Social Sciences. Version 5.0- McGraw-Hill Inc, Chicago IL,1975:675.

5. Bottini N, Bottini E, Gloria-Bottini F, Mustelin T. Low-molecular-weight protein tyrosine phosphatase and human disease: in search of biochemical mechanisms. Arch Immunol Ther Exp (Warsz). 2002;50:95-104.

6. Bottini N, Stefanini L, Williams S, Alonso A, Jascur T, et al. (2002) Activation of ZAP-70 through specific dephosphorylation at the inhibitory Tyr-292 by the low molecular weight phosphotyrosine phosphatase (LMPTP). J Biol Chem 277: 2422024224. [Crossref]

7. Chiarugi P, Cirri P, Marra F, Raugei G, Camici G, et al. (1997) LMW-PTP is a negative regulator of insulin-mediated mitotic and metabolic signalling. Biochem Biophys Res Commun 238: 676-682. [Crossref]

8. Stefani M, Caselli A, Bucciantini M, Pazzagli L, Dolfi F, et al. (1993) Dephosphorylation of tyrosine phosphorylated synthetic peptides by rat liver phosphotyrosine protein phosphatase isoenzymes. FEBS Lett 326: 131-134. [Crossref]

9. Vantler M, Karikkineth BC, Naito H, Tiburcy M, Didié M, et al. (2010) PDGFBB protects cardiomyocytes from apoptosis and improves contractile function of engineered heart tissue. J Mol Cell Cardiol 48: 1316-1323. [Crossref]

Copyright: (C2016 Gloria-Bottini F. This is an open-access article distributed under the terms of the Creative Commons Attribution License, which permits unrestricted use, distribution, and reproduction in any medium, provided the original author and source are credited. 